\title{
THE NEW PHYTOLOGIST
}

\author{
FOUNDED BY SIR ARTHUR TANSLEY IN 1902
}

\section{EDITED BY}
J. H. BURNETT
J. L. HARLEY
D. C. SMITH
R. G. WEST
JANLARY 1969
VOL. 68, NO. 1

A comparative study of bicarbonate inhibition of root growth in calcicole and calcifuge grasses. By J. A. LeE and H. W. WOOLHOUSE

Phosphate absorption by plants from habitats of different phosphate status. I. Absorption and incorporation of phosphate by excised roots. By H. NASSERY and J. L. HarLeY

Polyphosphate formation in the roots of Deschampsia flexurosa and Untica dioica. By $H$. NASSERY

A comparison of some properties of vicilin and legumin isolated from seeds of Pisum sativum, Vicia faba and Cicer arietimum. By P. JACKSON, D. BOULTER and D. A. THURMAN

Uptake and metabolism of exogenously supplied sugars by brown algae. By EDWARD A. DREW

Action spectra for photosynthesis and light-stimulated ion transport processes in Hydrodictyon africanum. By J. A. RAVEN

Stomatal responses to light and carbon dioxide in the Hart's-tongue fern, Phyllitis scolopendrium Newm. By T. A. MANSFIELD and C. M. WILLMER

Experiments on the juvenile-adult phase change in some woody species. By L. W. RoBinSON and P. F. WARFING

Age-governed responses of detached tomato leaves to phytokinins. By JANIECE S. MCHAle and Lewis D. Dove

Some experimental observations on the clone structure of a natural population of Festuca rubra L. By D. J. HARBERD and MYRFYN OWEN

Analytical studies of the growth of the etiolated seedlings of Avena sativa. III. The photosensitivity of the mesocotyl in relation to phosphate nutrition. By Heather Sabnis and C. L. Mer

The effects of fungi on morphogenesis of gametophytes of Polypodium vilgare $\mathbf{L}$. By D. L. SMITH and P. M. Robinson

Spore development in the brown rot fungi (Sclerotinia spp.). By H. J. Willetrs and F. D. CALONGE

Fusion, subsequent swelling and final dissolution of the apical walls of the progametangia of Rhizopus sexualis (Smith) Callen: an electron microscope study. By Lilian E. HaWker and Margaret A. Gooday

The ectotrophic mycorrhizas of Alnus viridis (Chaix) D.C. and their significance in respect to phosphorus uptake. By V. MeJsTRIK and U. BeNECKE

Cytotaxonomic variation in Potentilla fruticosa L. By T. T. ELKINGTON

The assessment of a method for the determination of absolute pollen frequencies. By J. MatThews

Structural variations in peat. By J. M. Stewart and S. E. Durno

Studies in the vegetational history of mid-Wales. 1. The Post-glacial period in Cardiganshire. By P. D. Moore and E. H. Chater

A note on the late-Weichselian Splachnum capsule from Scotland. By A. P. CoNolly and J. H. Dickson

Two pollen diagrams from the mainland, Orkney Islands. By N. T. MOAR

A radiocarbon dated pollen diagram from north-west Scotland. By N. T. MoAR

The subscription price per annual volume of four parts is 200 s. net, post free

BLACKWELL SCIENTIFIC PUBLICATIONS OXFORD AND EDINBURGH 


\title{
THE JOURNAL OF ECOLOGY
}

\author{
Editors: G. F. Asprey AND A. J. Willis \\ CONTENTS
}

Vol. 57 , No. 1

MARCH 1969

E. M. F. Swale. Phytoplankton in two English rivers.

Juliet C. Frankland. Fungal decomposition of bracken petioles

S. R. J. WOODEll, H. A. MOONEY and A. J. HiLl. The behaviour of Larrea divaricata (creosote bush) in response to rainfall in California

J. P. Grime and G. M. Blythe. An investigation of the relationships between snails and vegetation at the Winnats Pass

D. N. MCVeAn. Alpine vegetation of the central Snowy Mountains of New South Wales

Khalid Hamid Sheikr. The effects of competition and nutrition on the interrelations of some wet-heath plants

J. O. Rieley, D. Machin and A. Morton. The measurement of microclimatic factors under a vegetation canopy - a reappraisal of Wilm's method

G. C. Evans. The spectral composition of light in the field. I. Its measurement and ecological importance

P. J. Greenway and D. F. Vesey-Fitzgerald. The vegetation of Lake Manyara National Park

G. S. Hartley and J. W. G. MacLauchlan. A simple integrating thermometer for field use

R. H. Whittaker and G. M. Woodwell. Structure, production and diversity of the oak-pine forest at Brookhaven, New York

P. J. Grubb, H. E. Green and R. C. J. Merrifield. The ecology of chalk heath: its relevance to the ealcicole-calcifuge and soil acidification problems

Lesley D. Clarke and Nola J. Hannon. The mangrove swamp and salt marsh communities of the Sydney district. II. The holocoenotic complex with particular reference to physiography

R. M. M. CRAWFord and P. D. TYleR. Organic acid metabolism in relation to flooding tolerance in roots

G. A. Yarranton. Plant ecology: a unifying model

D. R. MARSHALL and S. K. JAIN. Interference in pure and mixed populations of Avena fatua and $A$. barbata

R. M. Newnham and A. Carlisle. The nitrogen and phosphorus nutrition of seedlings of Quercus robur L. and Q. petraea (Mattuschka) Liebl.

\section{BIOLOGICAL FLORA OF THE BRITISH ISLES}

P. J. Goodman, E. M. Braybrooks, J. M. Lambert and C. J. Marchant. Spartina Schreb.

Reviews

The subscription price per volume of 3 parts is 189 s. net, single parts 70 s. net

BLACKWELL SCIENTIFIC PUBLICATIONS LTD.

5 ALFRED STREET . OXFORD 


\section{NOTICE TO AUTHORS}

Papers and short notes from contributors anywhere in the world are welcome, and may be on any aspect of lichenology. They should be sent to the Editor. They must be typewritten in double or treble spacing, and a summary should generally be included. Illustrations should be in black ink on white paper, preferably Bristol board.

In taxonomic papers dealing with a series of species it is convenient either to present them alphabetically or to number them serially in their genera.

Localities in Britain should, unless there is good reason to the contrary, follow the spelling given on the latest editions of the maps published by the Ordnance Survey. Localities abroad should follow the spelling in The Times Atlas of the World.

The citation of references should be based on the International Code of Botanical Nomenclature 1966: 73-75.

Titles of periodicals should be abbreviated as in the latest edition of the World List of Scientific Periodicals. Titles of books should be given in full at the end of papers but may be judiciously abbreviated in lists of synonyms. Editions other than the first should be indicated.

\section{EXAMPLES:}

In text: Watson (1932), (Watson, 1932), or Watson (1932, p. 292).

In the list at end of paper: Watson, W. (1932) The bryophytes and lichens of moorland. 7. Ecol. 20: 284-313.

Or if a book: Crombie, J. M. (1894) A Monograph of Lichens Found in Britain. London.

In list of synonyms: Candelariella xanthostigma (Ach.) Lett. in Hedwigia, 52: 196 (1912).

Or if a book: Pyrenotea lutea Leight., British Species of Angiocarpous Lichens: 68, tab. 29, fig. 4 (1851).

Twenty-five reprints of original articles are supplied free. More may be purchased, as may reprints of other contributions such as book reviews. Reprints must be ordered when the author returns the final proofs of his article.

\section{MEMBERSHIP}

Membership of the British Lichen Society is open to all persons interested in lichenology. Subscriptions, due on joining and thence on 1 January each year, are: ordinary members, $£^{2}$; junior members, $£, 1$; family members, $5 \mathrm{~s}$. Details of membership and application forms may be obtained from the Secretary, Mr J. R. Laundon, Department of Botany, British Museum (Natural History), Cromwell Road, London, S.W.7.

\section{Referees}

The function of referees, whose names appear inside the front cover, is to assist members in the identification of lichens. Specimens submitted should be adequate in size and well documented, including details of country, county or vice-county, borough or parish, precise locality and grid reference, altitude, date, habitat and ecology, notes, name of collector and collecting number. Identification should be attempted before sending the specimens to a referee and details of spores and chemical reactions should be included where appropriate. Return postage should be enclosed. 


\section{THE LICHENOLOGIST}

Vol. 4 Part 2

1969

Imshaug, H. A. and Harris, R. C.-Parmentaria chilensis Fée

Kershaw, K. A. and Mrllbank, J. W.-A controlled environment lichen growth chamber

HensSEn, AINO-Three non-marine species of the genus Lichina

HensSen, AnNo-An interesting new species of Lempholemma from Canada 99-104

Hawksworth, D. L.-The lichen flora of Derbyshire 105-193

Follmann, Gerhard and Huneck, Siegrried-Notes on lichen substances. LVI. On the occurrence of erythrin in Chiodecton cretaceum Zahlbr.

Book Review

(C) British Lichen Society 1969

c/o Department of Botany, British Museum (Natural History), Cromwell Road, London, S.W.7.

Published for the British Lichen Society by Blackwell Scientific Publications Ltd, 5 Alfred Street, Oxford

Price $£^{2}(\$ 6.50)$. Free to members of the British Lichen Society. Annual subscription $£^{3}(\$ 10.00)$, post free Published April 1969 